\title{
Etiology of diarrheal disease among children under 5 years in Egypt: a high incidence of human bocavirus
}

Neveen M. Rizk ${ }^{1 \dagger}$, Sherif Abd-Elmaksoud ${ }^{1 \dagger}$, Tarek M. Farid ${ }^{2}$, Maha M. A. Abohashish², Ahmad Z. Al-Herrawy ${ }^{1}$ and Ibrahim A. Hamza ${ }^{1 *}$ (D)

\begin{abstract}
Background: Human bocavirus ( $\mathrm{HBOV}$ ) is globally distributed and associated with respiratory and enteric infections. Limited data are available about the incidence of HBoV in Egyptian children. We aimed to investigate the association of $\mathrm{HBOV}$ genotypes in children with diarrheal disease and also to determine the possibility of HBoV co-infections with other human enteric pathogens.

Methods: A total of 102 stool samples were collected from children under five years old with diarrhea. Samples were analyzed for the presence of HBoV by real-time PCR. HBoV positive samples were tested for adenovirus (AdV), rotavirus (RoV), parasitic helminths, and enteric protozoa.

Results: HBoV was detected in 58\% of examined cases. HBoV-3 was the most prevalent genotype observed (44\%; 45 of 102), followed by HBoV-2/4 (33\%; 34 of 102) and HBoV-1 (30\%; 31 of 102). Although the incidence of HBoV was higher in males (66.6\%; 34 of 51) than females (49\%; 25 of 51), the analysis showed no significant difference for HBoV between genders. The average HBoV concentrations were $5.3 \times 10^{4} \mathrm{GC} / \mathrm{g}$ in males and $1.03 \times 10^{5} \mathrm{GC} / \mathrm{g}$ in females. Among the HBoV-positive samples, the single infection of HBoV was $52.5 \%$ (31/59), while the co-infections with multiple viruses were found in 1.7\% (1/59) for HBoV and AdV, 33.9\% (20/59) for HBoV and RoV, and 11.9\% (7/59) for $\mathrm{HBoV}$, and RoV and AdV. No co-infection with parasitic helminths or enteric protozoa was found.

Conclusions: The single infection of $\mathrm{HBOV}$ in some children suffering from acute gastroenteritis indicated that HBoV could be the main etiologic agent of the disease. The study highlights the high incidence of HBoVs genotypes with remarkable multiple co-infections in the pre-school children in Egypt.
\end{abstract}

Keywords: Human bocaviruses, Adenovirus, Rotavirus, Co-infections, diarrhea, aPCR

\section{Introduction}

Diarrheal disease is the second most common cause of mortality worldwide in children less than 5 years and it is estimated that 600,000-700,000 infants and young children die from diarrhea each year. Most of the deaths occur in Sub-Saharan Africa and South Asia and mortality is high in children less than 5 years [1]. Mortality is

\footnotetext{
*Correspondence: ibrahimnrc@gmail.com

${ }^{+}$Neveen M. Rizk and Sherif Abd-Elmaksoud contributed equally to this work. 'Water Pollution Research Department, National Research Centre, $33 \mathrm{El}$ Buhouth St., Dokki, Giza 12622, Egypt

Full list of author information is available at the end of the article
}

uncommon in high-income countries, but diarrhea is often associated with substantial medical and healthcare costs. Viral diarrhea is a prevalent type of diarrhea in the world affecting patients of all ages, especially children [1]. Enteric viruses are the most frequent common pathogens causing diarrhea in high-income as well as low-income countries [2]. The most common agents are rotavirus (RoV), adenovirus (AdV), norovirus (NoV), sapovirus ( $\mathrm{SaV}$ ), and astrovirus (AstV). Additionally, bocaviruses (HBoVs) are increasingly being identified as causative agents of diarrhea [3]. However, little attention for HBoVs as a causative agent of diarrhea has been 
received so far, particularly the co-infections pattern of different $\mathrm{HBoV}$ s genotypes in pre-school children.

Human bocavirus (HBoV) was discovered in 2005 [4]. $\mathrm{HBoV}$ is a member of the family Parvoviridae, subfamily Parvovirinae, genus Bocaparvovirus. Four HBoV genotypes (HBoV-1-HBoV-4) have been identified and characterized by a $5.3 \mathrm{~kb}$ single-stranded DNA genome, encapsulated in a non-enveloped icosahedral capsid protein coat [5]. The genome of HBoV has three open reading frames (ORFs), encoding two nonstructural proteins NS1 and NP1 and two viral capsid proteins VP1 and VP2 [6].

A plethora of studies detected HBoVs in Europe [7], North America [8], South America [9], the Middle East [10], Asia [11], and Australia [12]. In African countries, HBoVs have been reported in Egypt 2\% (2/100 children of age from 1 month to 2 years) [13], Kenya 1.8\% (7/384 children/adults) [14], and South Africa 22.8\% (174/1460 children $<2$ years) [15]. As yet, little is still known about the prevalence of $\mathrm{HBoV}$ and its genotypes in Egypt, particularly in children.

HBoVs cause a variety of clinical manifestation and could be isolated from several types of clinical samples including nasopharyngeal aspirates $[12,16]$ and stool [17]. Furthermore, HBoVs was also found in environmental waters $[18,19]$. HBoV-1 is commonly associated with respiratory tract infections in pediatric patients, as well as in those with gastrointestinal symptoms [20]. In contrast, the other three genotypes (HBoV2-4) are found mainly in stool samples from patients suffering from gastroenteritis [21].

The association of $\mathrm{HBoV}$ with respiratory disease and acute gastroenteritis remains unclear due to the high rate of co-infection with other pathogenic viruses in symptomatic patients, as well as its frequent detection in asymptomatic individuals $[6,21]$. However, $\mathrm{HBoV}$ was isolated from hospitalized infants suffering from respiratory infections, without other respiratory viruses (i.e., adenovirus, respiratory syncytial virus, parainfluenza virus 1,2 , and 3 , human metapneumovirus, influenza virus A and B) [22]. Moreover, some reports found single infection of $\mathrm{HBoV}$ in the stool of infected patients with acute gastroenteritis (AGE), particularly among children under 5 years of age $[3,23]$. However, all children of different ages are at risk of $\mathrm{HBoV}$ infection as a result of poor hygiene practices and sanitation [23]. It is suspected that $\mathrm{HBoV}$ enters the bloodstream after a long period of persistence in the mucosa of the respiratory tract and migrates to the gastrointestinal tract, where it may either produce new infection or be excreted asymptomatically [24]. HBoVs can infect all human age groups, although severe infections were noticed in children [25] and patients with underlying diseases like cancer [26]. In this study, we specifically aimed to investigate the association of $\mathrm{HBoV}$ genotypes in children with AGE up to 5 years. Also, we screened the positive $\mathrm{HBoV}$ samples for AdV, RoV, parasitic helminths, and enteric protozoa to determine whether the causative agent of diarrhea in the collected samples is $\mathrm{HBoV}$ or co-infection with other pathogens.

\section{Methods}

\subsection{Sample collection}

A total of 102 stool samples were collected anonymously from preschool children (51 samples from males and 51 samples from females) from private clinics in Giza, Egypt. The samples were collected from children under 5 years of age suffering from acute watery diarrhea. Stool samples were examined immediately at the same day for parasites identification. In order to avoid repeated freezing and thawing, stool samples were aliquoted, stored at $-20^{\circ} \mathrm{C}$, and tested within a month from collection for $\mathrm{HBoV}$.

\subsection{Sample concentration and processing}

About $100 \mathrm{mg}$ of fecal diarrhea samples were weighed and diluted in phosphate buffer saline (1:10). The samples were vortexed for $30 \mathrm{~s}$ followed by centrifugation at $5000 \mathrm{rpm}$ for $10 \mathrm{~min}$ at room temperature. The supernatants were kept at $-80^{\circ} \mathrm{C}$ until further use.

\subsection{Nucleic acid extraction}

Viral nucleic acids were extracted from $200 \mu$ l of the concentrated sample using GeneJET Viral DNA and RNA Purification kit (Thermo Scientific-USA) according to the manufacturer's instructions. The obtained nucleic acid was dissolved in $60 \mu \mathrm{l}$ of eluent and kept at $-80{ }^{\circ} \mathrm{C}$ until use.

\subsection{Detection and quantification of HBoV by qPCR}

All primers used in the current study were listed in Table 1. The quantification protocol targeting the NP1 gene for $\mathrm{HBoV}-1$ was used according to Hamza et al. [18]. A single sense primer was shared in $\mathrm{HBoV}-2,3$, and 4 quantifications and the qPCR of $\mathrm{HBoV}-2$ and 4 used the same antisense primer [29]. SYBR green qPCR assay was conducted for $\mathrm{HBoVs}$ quantification using a Maxima SYBR Green qPCR Master Mix Kit (Thermo Scientifc). The PCR conditions were $10 \mathrm{~min}$ initial denaturation step at $95{ }^{\circ} \mathrm{C}, 40$ cycles of denaturation at 95 ${ }^{\circ} \mathrm{C}$ for $15 \mathrm{~s}$ and annealing-extension at $60{ }^{\circ} \mathrm{C}$ for $1 \mathrm{~min}$. Amplification was followed by one cycle of melting curve analysis. Dissociation was carried out from $60^{\circ} \mathrm{C}$ to $95^{\circ} \mathrm{C}$ with a temperature ramp of $0.05^{\circ} \mathrm{C} / \mathrm{s}$. Analysis indicated a melting peak $(\mathrm{Tm})$ at $83^{\circ} \mathrm{C} \pm 0.2^{\circ} \mathrm{C}$ for $\mathrm{HBoV}-1,81.5^{\circ} \mathrm{C} \pm 0.3^{\circ} \mathrm{C}$ for $\mathrm{HBoV} 2 / 4$, and $80^{\circ} \mathrm{C} \pm$ $0.2^{\circ} \mathrm{C}$ for $\mathrm{HBoV}-3$. PCR amplification and data analysis were performed by CFX 96 Realtime PCR machine (BioRad). The genome copy numbers of bocavirus genotypes 
Table 1 Primer sequences of HBoVs, AdV, and RoV

\begin{tabular}{|c|c|c|c|c|c|}
\hline Virus & Target gene & Primer name & Sequence $\left(5^{\prime}-3^{\prime}\right)$ & Fragment length (bp) & References \\
\hline \multirow[t]{2}{*}{ HBoV-1 } & NP1 & NP1-F2421 & TGGCAGACAACTCATCACAG & 123 & {$[22]$} \\
\hline & & NP1- R2544 & TCTTCGAAGCAGTGCAAGAC & & \\
\hline \multirow[t]{2}{*}{$\mathrm{HBoV}-2 / 4$} & NS1 & HBoV234F & GCACTTCCGCATYTCGTCAG & 100 & [29] \\
\hline & & HBoV24R & AGCAGAAAAGGCCATAGTGTCA & & \\
\hline \multirow[t]{2}{*}{ HBoV-3 } & NS1 & HBoV234F & GCACTTCCGCATYTCGTCAG & 100 & \\
\hline & & HBoV3R & GTGGATTGAAAGCCATAATTTGA & & \\
\hline \multirow[t]{4}{*}{ RoV } & VP6 & VP6-F & GACGGVGCRACTACATGGT & 382 & {$[40]$} \\
\hline & & VP6-R & GTCCAATTCATNCCTGGTG & & \\
\hline & & VP6-NF & GCTAGAAATITTGATACA & 147 & \\
\hline & & VP6-NR & TCTGCAGTTTGTGAATC & & \\
\hline \multirow[t]{2}{*}{ AdV } & Hexon & HexAA1885 & GCCGCAGTGGTCTTACATGCACATC & 300 & {$[31]$} \\
\hline & & Hex1913 & CAGCACGCCGCGGATGTCAAAGT & & \\
\hline
\end{tabular}

(HBoV-1, HBoV-2/4, and HBoV-3) were determined by comparison with a standard curve generated with serial dilutions of positive control of the PCR product from each genotype. The PCR product was purified using Wizard $^{\oplus}$ SV Gel and the PCR Clean-Up System (Promega, USA). Nucleic acid concentrations of the purified PCR products were determined by NanoDrop Fluorospectrometer (Thermo-Scientific, USA). The DNA concentration was converted to genomic copies using the following formula: number of DNA copies = $\left(\right.$ DNA amount $\left.(\mathrm{ng}) \times 6.022 \times 10^{23}\right) /($ length $(\mathrm{bp}) \times 1 \times$ $\left.10^{9} \times 650\right)$.

The standard curve of each bocavirus was separately prepared by tenfold serial dilution of the nucleic acid standard ranging from $5 \times 10^{1}$ to $5 \times 10^{7}$ copies/reaction. For HBoV-1 and HBoV-3, the slop was - 3.69; the coefficient of determination $\left(\mathrm{R}^{2}\right)$ was 0.99 . In the case of $\mathrm{HBoV}-2 / 4$, the mean value of the slope was - 3.45; the mean of $\mathrm{R}^{2}$ was 0.99 . Virus concentration per gram (g) $\mathrm{GC} / \mathrm{g}$ was calculated according to the following equation: $G C / g=G C x D F \times 10$, where $\mathrm{GC}$ is genome copy number per reaction, DF is the dilution factor for the volume reductions that occur during the concentration, DNA extraction, and qPCR steps, and the obtained GC was expressed per gram of stool sample.

\subsection{Detection of rotavirus and adenovirus}

The positive samples for $\mathrm{HBoV}$ were tested for RoV and AdV to determine the pathogen co-infections. RoV was detected by using nested RT-PCR for the detection of the VP6 segment [30]. AdV was detected according to Puig et al. [31] using primers based on the hexon gene (Table 1).

2.6 Detection of enteric protozoa and helminth parasites The positive samples for $\mathrm{HBoV}$ were tested for enteric protozoa and helminth parasites by microscopic examination (direct wet-mount preparation) [32] to differentiate whether AGE originated from $\mathrm{HBoV}$ or other causative agents.

\subsection{Statistical analyses}

Statistical analyses were performed using GraphPad Prism version 8.3.0 software (USA). The critical $P$ value for the test was set at $<0.05$. One-way ANOVA shows the significant difference between the relative distribution of different bocavirus genotypes in total, male and female stool samples. The unpaired $t$ test was used to compare each $\mathrm{HBoV}$ genotype in male versus female stool samples.

\section{Results}

3.1 Detection and quantification of human bocaviruses In the present study, human bocavirus genotypes were detected in 58\% (59 of 102, $P<0.05$ ) of the children stool samples using qPCR, which targets NP-1 and NS-1 genes. Statistically, the viral type showed a significant effect on the prevalence of $\mathrm{HBoV}$ in males $(P=<0.0001)$, although no significant influence on the prevalence of the virus in females $(P=0.27)$. The detection rates of different $\mathrm{HBoV}$ genotypes are presented in Table 2.

\subsection{HBoV-1}

HBoV-1 was detected in 31 out of 102 stool samples. The positive samples were $37 \%$ from males and $23 \%$ from females, in accordance with the number of samples collected from each gender (Table 2). Statistically, there was no significant difference between male and female patients who were infected with $\mathrm{HBoV}-1(P=0.22)$. In other words, gender had no significant effect on the prevalence of $\mathrm{HBoV}-1$. The average viral concentration was $1.0 \times 10^{4} \mathrm{GC} / \mathrm{g}$ in males and $1.3 \times 10^{4} \mathrm{GC} / \mathrm{g}$ in $\mathrm{fe}-$ males (Fig. 1). 
Table 2 Detection rates of bocaviruses genotypes in stool samples of under five children, Giza, Egypt

\begin{tabular}{|c|c|c|c|}
\hline & \multicolumn{3}{|c|}{ Prevalence $\mathrm{n} / \mathrm{N}(\%)$} \\
\hline & Male & Female & Total \\
\hline \multicolumn{4}{|l|}{ Bocavirus infection } \\
\hline HBoV-1 & 19/51 (37.3\%) & $12 / 51(23.5 \%)$ & $31 / 102(30.4 \%)$ \\
\hline HBoV-2/4 & 20/51 (39.2 \%) & $14 / 51(27.5 \%)$ & 34/102 (33.3\%) \\
\hline $\mathrm{HBOV}-3$ & 25/51 (49\%) & 20/51(39.2\%) & $45 / 102(44.1 \%)$ \\
\hline \multicolumn{4}{|l|}{ One genotype $(n=20 / 59,34 \%)$} \\
\hline HBoV-1 & $2 / 34(5.9 \%)$ & $1 / 25(4 \%)$ & $3 / 59(5 \%)$ \\
\hline HBoV-2/4 & $4 / 34(11.8 \%)$ & $3 / 25(12 \%)$ & $7 / 59(12 \%)$ \\
\hline $\mathrm{HBOV}-3$ & $5 / 34(14.7 \%)$ & $5 / 25(20 \%)$ & 10/59 (17\%) \\
\hline \multicolumn{4}{|l|}{ Two genotypes ( $n=27 / 59,46 \%)$} \\
\hline $\mathrm{HBoV}-1+\mathrm{HBoV}-2 / 4$ & $3 / 34(8.8 \%)$ & $1 / 25(4 \%)$ & $4 / 59(6.7 \%)$ \\
\hline $\mathrm{HBOV}-1+\mathrm{HBOV}-3$ & $7 / 34(20.6 \%)$ & $5 / 25(20 \%)$ & $12 / 59(20.3 \%)$ \\
\hline $\mathrm{HBoV}-2 / 4+\mathrm{HBOV}-3$ & $6 / 34(17.6 \%)$ & $5 / 25(20 \%)$ & $11 / 59(18.6 \%)$ \\
\hline \multicolumn{4}{|l|}{ Three genotypes ( $n=12 / 59,20 \%)$} \\
\hline $\mathrm{HBoV}-1+\mathrm{HBoV}-2 / 4+\mathrm{HBoV}-3$ & 7/34 (20.6\%) & $5 / 25(20 \%)$ & $12 / 59(20 \%)$ \\
\hline
\end{tabular}

$n$ number of bocavirus positive cases, $N$ total number of cases

\subsection{HBoV-2/4}

HBoV-2/4 virus was detected in 34 out of 102 samples. The prevalence of $\mathrm{HBoV}-2 / 4$ was higher in males $(39.2$ $\%)$ than females (27.5\%) (Table 2). Similar to $\mathrm{HBoV}-1$, no critical role played by the gender on the prevalence of $\mathrm{HBoV}-2 / 4(P=0.4254)$. The average viral concentrations were $1.3 \times 10^{5} \mathrm{GC} / \mathrm{g}$ and $2.6 \times 10^{5} \mathrm{GC} / \mathrm{g}$ in males and females, respectively (Fig. 1).

\subsection{HBoV-3}

HBoV-3 showed a high prevalence $(44.1 \%)$ in total samples compared to other $\mathrm{HBoV}$ types. The prevalence of HBoV-3 was higher in males (49 \%) than females (39.2\%) (Table 2). HBoV-3 had the same pattern as

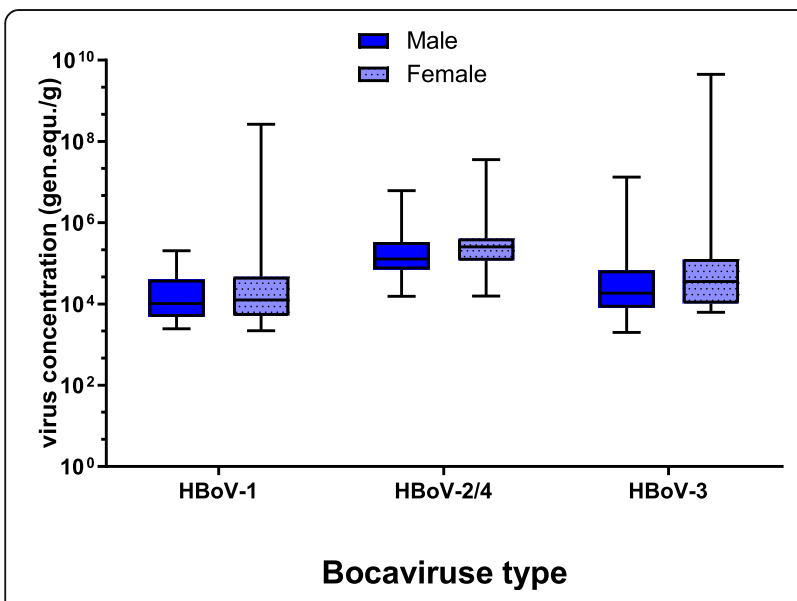

Fig. 1 Concentration of bocaviruses in male and female stool samples of under five children
$\mathrm{HBoV}-1$ as well as $\mathrm{HBoV}-2 / 4$ in males versus females. The mean virus concentration in male and female samples reached $1.9 \times 10^{4}$ and $3.6 \times 10^{4} \mathrm{GC} / \mathrm{g}$, respectively (Fig. 1).

\subsection{HBoV genotype co-infections}

Among the positive samples, single genotypes detected in $34 \%(20 / 59)$ of $\mathrm{HBoV}$ positive cases and two or more genotypes detected in $66 \%(39 / 59)$ of $\mathrm{HBoV}$ positive cases. The most common mixed genotype cases were HBoV-1 and HBoV-3 (20.3\%), followed by HBoV-2/4 and HBoV-3 (18.6\%) and HBoV-1 andHBoV-2/4 (6.7\%) (Table 2).

\subsection{HBoV and other enteric pathogen co-infections}

The positive samples for $\mathrm{HBoV}(\mathrm{n}=59)$ were screened for other viruses (i.e., AdV and RoV), protozoa, and parasitic helminths to explore whether AGE originated from bocavirus or other causative agents. The single infections of $\mathrm{HBoV}$ in males and females were $61.8 \%$ (21/ $34)$ and $40 \%(10 / 25)$, respectively, while the coinfections ratios of $\mathrm{HBoV} / \mathrm{AdV}, \mathrm{HBoV} / \mathrm{RoV}$, and $\mathrm{HBoV} /$ RoV/AdV in males were $2.9 \%$ (1/34), 26.5\% (9/34), and $8.8 \%(3 / 34)$, respectively. In females, multiple infections of $\mathrm{HBoV} / \mathrm{RoV}$ and $\mathrm{HBoV} / \mathrm{RoV} / \mathrm{AdV}$ account for $44 \%$ $(11 / 25)$ and $16 \%$ (4/25), respectively (Fig. 2). Protozoa and parasitic helminths could not be detected in fecal samples of the children suffering from viral infections.

\section{Discussion}

Different viruses including RoV, AdV, NoV, and AstV are the major cause of gastrointestinal disease 


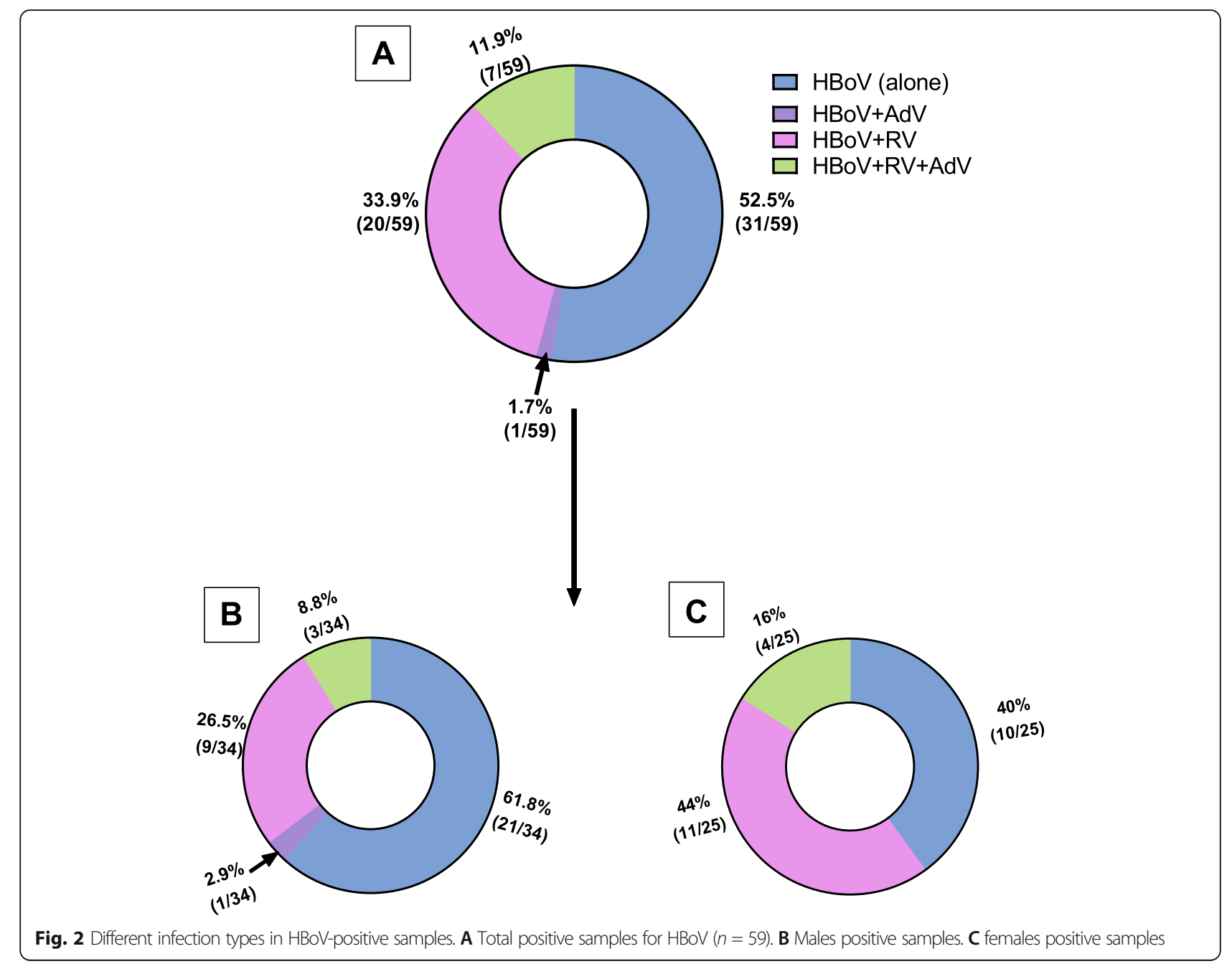

worldwide, particularly in developing countries. Globally, $\mathrm{HBoV}$ has been associated with about $5.9 \%$ of gastrointestinal illnesses and $6.3 \%$ of respiratory tract infections $[6,12]$ and has been reported in various studies as a potential cause of diarrhea outbreaks [33]. It was estimated that $13 \%$ of African individuals suffering from gastroenteritis principally caused by $\mathrm{HBoVs}$ between 2005 and 2016 [23]. To our knowledge, limited data are available about the incidence of $\mathrm{HBoV}$ in Egyptian children. Only two clinical studies were reported in Egypt; the first study found HBoV in Children with AGE [13]. The second study observed $\mathrm{HBoV}-1$ in children suffering from lower respiratory tract infections without providing any data about different genotypes in the given cases [27]. However, HBoV-1, HBoV-2, and HBoV-3 were detected in environmental samples from Egypt [19]. Therefore, it is crucial to determine the prevalence of $\mathrm{HBoV}$ genotypes in children $<5$ years of age, who are most vulnerable to $\mathrm{HBoV}$ infections.

Our results showed that the proportion of the single infection of $\mathrm{HBoV}(52.5 \%, 31 / 59)$ was higher than co- infection with $\mathrm{AdV}$ and $\mathrm{RoV}$, indicating the possible contribution of the virus in the pathogenicity. In contrast, infection with $\mathrm{HBoV}$ in Pakistani children was not significantly associated with gastroenteritis alone where 98\% of $\mathrm{HBoV}$ reported cases had co-infection with RoV [34]. The co-infection of $\mathrm{HBoV}$ and $\mathrm{RoV}$ (46\%) in patients with gastrointestinal infections has been recorded elsewhere [6]. In this study, mixed infections with the three viruses ( $\mathrm{HBoV}, \mathrm{AdV}$ and $\mathrm{RoV}$ ) were detected in $11.9 \%$ of HBoV-positive samples. Likewise, the mixed infections with (Aichivirus, sapovirus, human parechoviruses, bocavirus, and rotaviruses) were detected in $45.4 \%$ of the stool samples from Indian children $<5$ years of age hospitalized for acute gastroenteritis [28].

In the present study, the prevalence of $\mathrm{HBoV}$ in children suffering from AGE was $58 \%$ which is higher than the previous reports of $\mathrm{AGE}$ associated with $\mathrm{HBoV}$ in Egypt (2\%) [13], Brazil (24 and 42\%) [35], and Taiwan $(8.5 \%)$ [36]. This difference in detection rate could be attributed to the difference of sensitivity of the detection method, geographical region, hygiene and sanitary 
conditions, and/or the sample size of the study. HBoV has been detected in stool samples of both children and adults; however, children $\leq 2$ years of age were found to be most susceptible to $\mathrm{HBoV}$ infection [23]. In our study, we detected $\mathrm{HBoV}-1, \mathrm{HBoV} 2 / 4$, and $\mathrm{HBoV}-3$. Likewise, all genotypes have been detected in USA (children), Finland (children/adults), Japan (children), Kenya (children/adults), and Turkey (children) [23]. The most abundant $\mathrm{HBoV}$ type in the current study was HBoV3. In contrast, $\mathrm{HBoV} 1$ was the most prevalent in urban and rural settings followed by HBoV-2 [12, 23, 34]. The differences in $\mathrm{HBoV}$ genotypes abundance may be due to regional differences in viral epidemiology or because not all the studies tested all $\mathrm{HBoV}$ genotypes or the lately discovered genotypes (i.e., $\mathrm{HBoV}-2 / 4$ and $\mathrm{HBoV}-3$ ) compared to HBoV-1. HBoV was found in $9 \%$ of nasopharyngeal swabs obtained from children with acute respiratory tract infection in Alexandria, Egypt [37]. The $\mathrm{HBoV}-1$ was the only genotype detected, suggesting that a single genetic lineage of $\mathrm{HBoV}$ is circulating in Egypt [37]. However, in the present study, HBoV-3 was the most abundant genotype which could be due to the difference in samples types. Furthermore, the relative abundance of $\mathrm{HBoV}-2$ and $\mathrm{HBoV}-3$ compared to HBoV-1 may be due to differences in tissue tropism or pathogenesis among $\mathrm{HBoV}$ genotypes, which may affect transmission and persistence.

In the present study, the viral incidence was higher in males $66.6 \%$ than females $49 \%$ and the difference was statistically non-significant $(p>0.05)$. The current results agree with the study of Nawaz et al. [38] from the UK, who reported that the distribution of $\mathrm{HBoV}$ among females and males was not significantly different, which recorded $53 \%$ and $47 \%$ in females and males, respectively. Similarly in Brazil, the researchers found that $57 \%$ of $\mathrm{HBoV}$ positive cases were detected in boys and $43 \%$ were detected in girls [39]. In another study in Pakistan, the researchers found $\mathrm{HBoV}$ infection rates were higher in males (68\%) as compared to females (32\%) [34].

\subsection{Limitations of the study}

Our study had some limitations such as the lack of a healthy control group and screening of other enteric pathogens (e.g., bacteria, sapovirus, norovirus, or astrovirus).

\section{Conclusions}

The presence of $\mathrm{HBoV}$ in some children suffering from AGE without the association of any other etiological agents (i.e., AdV, RoV, protozoa and parasitic helminths) indicates the ability of the virus to cause the disease. $\mathrm{HBoV}$ was abundant in stool samples from children with gastrointestinal disease in Egypt. Higher infection rates were detected in males rather than females. However, the viral loads were higher in females than in males. HBoV-3 was the most abundant among $\mathrm{HBoV}$ genotypes. Higher proportions of multiple co-infection of $\mathrm{HBoV}$ genotypes were recorded compared to single infections. The viral type had a strong significant effect on the prevalence of $\mathrm{HBoV}$ rather than human gender. Moreover, the concentration of $\mathrm{HBoV}-2 / 4$ was higher than $\mathrm{HBoV}-1$ as well as HBoV-3. Taken together, the data obtained in our study raise a concern on the role of $\mathrm{HBoV}$ in gastrointestinal illness.

\section{Abbreviations}

ANOVA: Analysis of variance; HBoV: Human bocavirus; AGE: Acute gastroenteritis; AdV: Adenovirus; RoV: Rotavirus; NoV: Norovirus;

SaV: Sapovirus; AstV: Astrovirus; GC/g: Gene copy per gram; RPM: Revolutions per minute; n: Number; P: P value; RT-PCR: Reverse transcription polymerase chain reaction; DF: Dilution factor; ORFs: Open reading frames; qPCR: Realtime PCR; $R^{2}$ : The coefficient of determination; UK: United Kingdom; USA: United States of America

\section{Acknowledgements}

Not applicable.

\section{Authors' contributions}

NR: conceptualization, formal analysis, writing-original draft, visualization, funding acquisition. SA: validation, writing — review and editing, study concept and design. TF: investigation, writing-review, interpretation of the data. MA: investigation, visualization, writing-review. AA: methodology, parasitology analysis and review. IH: conceptualization, methodology, supervision and writing the manuscript. All authors have read and approved the manuscript.

\section{Funding}

This study was funded by National Research Centre, Cairo, Egypt, project number 12030103.

\section{Availability of data and materials}

The datasets used and analyzed during the current study are available from the corresponding author upon reasonable request.

\section{Declarations}

Ethical approval and consent to participate

Ethical approval and consent to participate: The study was conducted with the approval of The Medical Research Ethics Committee (MREC), National Research Centre, Egypt (approval no. 20-165). A written informed consent was obtained from all participants' parents after explaining the aim of the study.

Consent for publication

Not applicable.

\section{Competing interests}

The authors declared that there was no conflict of interest.

\section{Author details}

${ }^{1}$ Water Pollution Research Department, National Research Centre, $33 \mathrm{El}$ Buhouth St., Dokki, Giza 12622, Egypt. ${ }^{2}$ Pediatric Department, National Research Centre, 33 El Buhouth St., Dokki, Giza 12622, Egypt.

Received: 11 December 2020 Accepted: 22 June 2021 Published online: 05 August 2021

\section{References}

1. Liu L, Oza S, Hogan D, Chu Y, Perin J, Zhu J, et al. Global, regional, and national causes of under-5 mortality in 2000-15: an updated systematic analysis with implications for the Sustainable Development Goals. Lancet. 2016;388(10063):3027-35. 
2. Green RJ. Viral infections in children, volume II. Publishing SI, editor. Viral Infections in Children, Volume II. 2017. 1-224 p.

3. De R, Liu L, Qian Y, Zhu R, Deng J, Wang F, et al. Risk of acute gastroenteritis associated with human bocavirus infection in children: a systematic review and meta-analysis. PLoS One. 2017;12(9):e0184833.

4. Allander T, Tammi MT, Eriksson M, Bjerkner A, Tiveljung-Lindell A, Andersson B. Cloning of a human parvovirus by molecular screening of respiratory tract samples. Proc Natl Acad Sci USA. 2005;102(36):12891-6.

5. Schildgen O, Qiu J, Sderlund-Venermo M. Genomic features of the human bocaviruses. Future Virol. 2012;7(1):31-9.

6. Guido M, Tumolo MR, Verri T, Romano A, Serio F, De Giorgi M, et al. Human bocavirus: current knowledge and future challenges. World J Gastroenterol. 2016:22(39):8684-97.

7. Bonzel L, Tenenbaum T, Schroten H, Schildgen O, Schweitzer-Krantz S, Adams $\mathrm{O}$. Frequent detection of viral coinfection in children hospitalized with acute respiratory tract infection using a real-time polymerase chain reaction. Pediatr Infect Dis J. 2008;27(7):589-94.

8. Albuquerque MCM, Pena GPA, Varella RB, Gallucci G, Erdman D, Santos N. Novel respiratory virus infections in children. Brazil. Emerg Infect Dis. 2009; 15(5):806-8

9. Ghietto LM, Cámara A, Cámara J, Adamo MP. High frequency of human bocavirus 1 DNA in infants and adults with lower acute respiratory infection. J Med Microbiol. 2012;61(4):548-51.

10. Kaplan NM, Dove W, Abu-Zeid AF, Shamoon HE, Abd-Eldayem SA, Hart CA. Human bocavirus infection among children. Jordan Emerg Infect Dis. 2006; 12(9):1418-20.

11. Pham NTK, Trinh QD, Chan-It W, Khamrin P, Nishimura S, Sugita K, et al. Human bocavirus infection in children with acute gastroenteritis in Japan and Thailand. J Med Virol. 2011;83(2):286-90.

12. Arthur JL, Higgins GD, Davidson GP, Givney RC, Ratcliff RM. A novel bocavirus associated with acute gastroenteritis in Australian children. PLoS Pathog. 2009;5(4):e1000391.

13. El-Mosallamy WA, Awadallah MG, Abd El-Fattah MD. Human bocavirus among viral causes of infantile gastroenteritis. Egypt J Med Microbiol. 2015; 24(3):53-9.

14. Misigo D, Mwaengo D, Mburu D. Molecular detection and phylogenetic analysis of Kenyan human bocavirus isolates. J Infect Dev Ctries. 2014; 8(2): 221-7.

15. Nunes MC, Kuschner Z, Rabede Z, Madimabe R, Van Niekerk N, Moloi J, et al. Clinical epidemiology of bocavirus, rhinovirus, two polyomaviruses and four coronaviruses in HIV-infected and HIV-uninfected South African children. PLoS One. 2014;9(2):e86448.

16. Koseki N, Teramoto S, Kaiho M, Gomi-Endo R, Yoshioka M, Takahashi Y, et al. Detection of human bocaviruses 1 to 4 from nasopharyngeal swab samples collected from patients with respiratory tract infections. J Clin Microbiol. 2012;50(6):2118-21.

17. Okitsu S, Khamrin P, Takanashi S, Thongprachum A, Hoque SA, Takeuchi H, et al. Molecular detection of enteric viruses in the stool samples of children without diarrhea in Bangladesh. Infect Genet Evol. 2020;77:104055.

18. Hamza IA, Jurzik L, Stang A, Sure K, Überla K, Wilhelm M. Detection of human viruses in rivers of a densly-populated area in Germany using a virus adsorption elution method optimized for PCR analyses. Water Res. 2009; 43(10):2657-68

19. Hamza H, Leifels M, Wilhelm M, Hamza IA. Relative abundance of human bocaviruses in urban sewage in Greater Cairo. Egypt. Food Environ Virol. 2017;9(3):304-13.

20. Netshikweta R, Chidamba L, Nadan S, Taylor MB, Page NA. Molecular epidemiology of human bocavirus infection in hospitalized children with acute gastroenteritis in South Africa, 2009-2015. J Med Virol. 2020;92(8): $1124-32$.

21. Ong DSY, Schuurman R, Heikens E. Human bocavirus in stool: a true pathogen or an innocent bystander? J Clin Virol. 2016;74:45-9.

22. Durigon GS, Oliveira DBL, Vollet SB, Storni JG, Felício MCC, Finelli C, et al. Hospital-acquired human bocavirus in infants. J Hosp Infect. 2010;76(2): 171-3.

23. Rikhotso MC, Kabue JP, Ledwaba SE, Traoré AN, Potgieter N. Prevalence of human bocavirus in Africa and other developing countries between 2005 and 2016: a potential emerging viral pathogen for diarrhea. J Trop Med. 2018;2018:7875482.

24. Schildgen O. Human bocavirus: lessons learned to date. Pathogens. 2013; 2(1):1-12.
25. Heydari H, Mamishi S, Khotaei G-T, Moradi S. Fatal type 7 adenovirus associated with human bocavirus infection in a healthy child. J Med Virol. 2011;83(10):1762-3.

26. Kupfer B, Vehreschild J, Cornely O, Kaiser R, Plum G, Viazov S, et al. Severe pneumonia and human bocavirus in adult. Emerg Infect Dis. 2006;12(10): 1614-6.

27. Abdel-Moneim AS, Kamel MM, Hamed DH, Hassan SS, Soliman MS, AlQuraishy SA, et al. A novel primer set for improved direct gene sequencing of human bocavirus genotype-1 from clinical samples. J Virol Methods. 2016;228:108-13.

28. Tatte VS, Gopalkrishna V. Detection of different enteric viruses in children with diarrheal disease: evidence of the high frequency of mixed infections. Access Microbiol. 2019;1(2):e000010.

29. Kantola K, Sadeghi M, Antikainen J, Kirveskari J, Delwart E, Hedman K, et al. Real-time quantitative PCR detection of four human bocaviruses. J Clin Microbiol. 2010;48(11):4044-50.

30. Iturriza-Gómara M, Dallman T, Bányai K, Böttiger B, Buesa J, Diedrich S, et al. Rotavirus genotypes co-circulating in Europe between 2006 and 2009 as determined by EuroRotaNet, a pan-European collaborative strain surveillance network. Epidemiol Infect. 2011;139(6):895-909.

31. Puig M, Jofre J, Lucena F, Allard A, Wadell G, Girones R. Detection of adenoviruses and enteroviruses in polluted waters by nested PCR amplification. Appl Environ Microbiol. 1994;60(8):2963-70.

32. Garcia LS, Arrowood M, Kokoskin E, Paltridge GP, Pillai DR, Procop GW, et al. Laboratory diagnosis of parasites from the gastrointestinal tract. Clin Microbiol Rev. 2018:31(1):1-81.

33. Bastien N, Brandt K, Dust K, Ward D, Li Y. Human Bocavirus infection, Canada. Emerg Infect Dis. 2006;12(5):848-50.

34. Alam MM, Khurshid A, Shaukat S, Sharif S, Suleman RM, Angez M, et al. Human bocavirus in Pakistani children with gastroenteritis. J Med Virol. 2015;87(4):656-63.

35. Soares LS, Lima ABF, Pantoja KC, Lobo PS, Cruz JF, Guerra SFS, et al. Molecular epidemiology of human bocavirus in children with acute gastroenteritis from north region of Brazil. J Med Microbiol. 2019;68(8): 1233-9.

36. Lin MYC, Chan HC, Chi H, Chiu SC, Nora-Krukle Z, Rasa-Dzelzkaleja S, et al. Genetic diversity and phylogenetic analysis of human bocavirus 2 in pediatric patients with acute gastroenteritis in Taiwan. Int J Environ Res Public Health. 2020;17(3):1-9.

37. Abozahra R, Abdelhamid SM, Khairy K, Baraka K. Detection and phylogenetic analysis of human bocavirus in children diagnosed with acute respiratory tract infection. J Med Microbiol. 2020;69(9):1197-202.

38. Nawaz S, Allen DJ, Aladin F, Gallimore C, Iturriza-Gómara M. Human bocaviruses are not significantly associated with gastroenteritis: Results of retesting archive DNA from a case control study in the UK. PLoS One. 2012; 7(7):e41346.

39. Albuquerque MCM, Rocha LN, Benati F, Soares CC, Maranhão AG, Ramirez $\mathrm{ML}$, et al. Human bocavirus infection in children with gastroenteritis, Brazil. Emerg Infect Dis. 2007;13(11):1756-8.

40. Gray J, Iturriza-Gómara M. Rotaviruses. Methods Mol Biol. 2011;665:325-55.

\section{Publisher's Note}

Springer Nature remains neutral with regard to jurisdictional claims in published maps and institutional affiliations. 